\title{
Lyric Hero Spiritual World And Creative Worldwide
}

\author{
Nasiba Bozorova Po'lotjonovna, \\ Candidate of Philological Sciences, Tashkent State Law University, Associate Professor of Uzbek Language and Literature. \\ Tashkent, Uzbekistan.n.bozorova@tsul.uz
}

\begin{abstract}
The article emphasizes that in the study of the creative personality and worldview in art, his beliefs, confession of heart, life position, activity, attitude to the artistic word - all should be taken into account and studied on this basis. It is also possible to solve this problem by studying the poetics of the hero created by the creator. In prose, the image and interpretation of the protagonist plays a key role in the assessment of the author's personality, and in poetry the scientific interpretation of Alisher Navoi's lyrical hero.
\end{abstract}

Keywords:

artistic creation, interpretation, worldview, lyrical hero, Qur'an, obid, arif, lover, poverty, interpretation, image.

Article Received: 18 October 2020, Revised: 3 November 2020, Accepted: 24 December 2020

Since the creation of man, he has been striving to understand, to know, to study existence. Although the tools and methods are different, the essence is only one. Among the methods of cognition, the place of the artistic word is fragmentary. It can be said that the power of image and influence of the artistic word is boundless. After all, this method originated as an imitation of the art of the Seed, which created infinity with a limited number of letters. That is why religion, politics, law, morality, ethics and aesthetics - all rely on the power of artistic expression to popularize, expand, spread, live. Artistic creation is not only the product of consciousness, but also the product of emotion, heart and soul, the product of thinking and imagination. It has the property of i'jaz (miracle). That is why everyone appeals to him and feels the need for him. The masters of artistic expression discussed the problems of the world and man through the images of the spiritual and spiritual world of the protagonist, which is an indicator of the creative worldview, imagination and thinking.

In the study of the artist's personality and worldview in art, it is necessary to take into account his beliefs, confession of heart, life position, activity, attitude to the artistic word - all and study on this basis. This can also be solved by studying the poetics of the hero created by the creator. In prose, the image and interpretation of the protagonist play a major role in the assessment of the author's personality, while in poetry, the image and interpretation of the lyrical hero. In literary criticism, the protagonist plays an important role in determining the content, philosophical value, historical and national features of the work, the socio-political landscape of the period. and is interpreted as a poetic image, reflecting his own image, whose personality and "biography" are very similar to those of the poet, and which assimilates a number of features from the ideal "I" of the poet. Therefore, when it comes to the content of the work of art, the artistic and aesthetic value of the creative worldview, thinking, of course, first of all, refers to the main character - the main character. Through the attitude to the spiritual world of the protagonist of a poetic or prose work, the artistic analysis and interpretation is carried out correctly, and the ideological purpose of the author is fully clarified.

This approach is very correct in the study and analysis of the poetry of our classic poets, especially Alisher Navoi. Because the poet's worldview, experiences and feelings are understood through the image of the lyrical hero. In the words of Navoi scholar A. Hayitmetov, "the 
heart of a lyrical hero receives warmth from the heart of a poet, the mind of a lyrical hero thinks with the mind of a poet,"

In literary criticism, the problem of Navoi's lyrical hero has been specially studied by our scholars such as Maqsud Shaykhzoda, Abdukodir Hayitmetov, Botirkhan Akram. A number of other scientists have also expressed their views on this issue in their research. Most of the studied works note that in Alisher Navoi's poetry the lyrical hero comes as a lover, rind, arif, rind, ascetic, thinker, and the lyrical hero is approached from the point of view of the former Soviet ideology. Due to the demands of the politics of the time, the problem of the extremely lyrical hero in Navoi's poetry has been studied very narrowly. More precisely, the ideology of that time did not allow to study Alisher Navoi's religious views, the main images that illuminate the poet's attitude to mysticism (believer, obid, sufi, dervish, zahid, zokir, abror, abdol, faqir, siddiq). Due to the achievement of freedom of language and religion, an objective approach to this issue began, and today in the works of our Navoi scholar Alisher Navoi studied the images of the poor and the learned. After the independence of the country, Alisher Navoi's personality was not modernized, but began to be valued.

We know that for classical works, the main criterion was whether or not there was a benefit to understanding the language of the Qur'an. For this reason, the creators relied on the wisdom of the Qur'an in finishing their works with great skill and sophistication, and Turkish writers in particular paid special attention to this. Alisher Navoi's lyrical protagonist, who lived with the confidence that the knowledge of the truth would be formed by affirming and following his rulings, is also, first of all, a true Muslim of Islamic faith. Therefore, the poet's lyrical protagonist can be called a believer, a believer, who first of all embodied the word monotheism in his soul. The work of Alisher Navoi, who memorized the Qur'an from a young age and enlightened his heart, life and dreams with it, served to propagate the enlightenment of the divine WORD. "Navoi deeply immersed the spirit of the Qur'an in Uzbek literature, skillfully used the method of advice in the Qur'an," writes Navoi scholar A. Hayitmetov. Indeed, in all the works of the great poet, the influence of the content, style and idea of the Qur'an is evident. This is also observed in the image of the lyrical hero created by the poet.

Alisher Navoi's lyrical protagonist is determined by the inclination of the enlightenment of the Truth, the level of knowledge of the Truth, the power and light of faith. If we read the poems of the great poet carefully, we will fully admit it. In the ghazals, the poet draws human experiences and feelings in such a way that these lines speak of the spiritual status, enlightenment status and level of the lyrical hero, and the clever poet can accurately determine the position of the lyrical hero in Truth and human history. The state of the lyrical hero, his experiences, as well as the poetic expression, symbols and emblems in the ghazal are understood as leeches, and Navoi's lyrical hero is not only a lover, arif, rind, zahid, but also obid, talib, sufi, dervish, abror, arif, ghani, muhayy. , make sure it is a fan. For example, how is the image of a Taliban and a lover in the demands of the Truth described in Alisher Navoi's ghazals? Let's think about this first.

In fact, man seeks in the true sense of the word: someone wants the world, someone wants the world, and someone wants the world. It is from this sense of ambition that the soul works, toils, and toils. Desires create action. Action, research, hard work - the basis of self-discovery, the threshold of the destination. Inaction is alien to the Taliban. The first condition of the Taliban is to give up everything except what is required (to give up everything that is not required, to start oneself at the destination). "In the status of demand, which is the first stage in the path of the sect, the desire (that is, the slave who wants, the needy) is not satisfied with a simple level of piety, but awakens the desire to reach the Truth, to become a higher person. In awakening the desire to be a perfect human being, as an ordinary believer, the Shari'a and the Qur'an, based on the hadiths, are aware of the Absolute Truth, Allah 
and His infinite attributes. the pursuit of greatness is the impetus. "Ghazals in demand status speak of the beauty of Yor, its infinite power, virtue and delicacy, humor and grace. This characteristic attracts the Taliban, and the desire to find it does not leave the heart at peace for a moment. The agony of search, danger, fear, excitement, and hope moves into the word, and the lyrical protagonist confesses, "It is difficult to find you, it is easy not to find you. The lyrical protagonist's heart is burning with passion, attachment, attachment, passion. The passion for captivity does not leave him for a moment, the acquaintance grows moment by moment, and the poet does not shy away from expressing his grief to the lyrical hero:

I've had a hard time seeing the beauty,

What a honeymoon I was, I became acquainted with you.

Although I said that day by day your heart,

Revelation, I became more and more confused day by day (49).

Nothing is apparent in the appearance of the captive Taliban. All the pain, all the passion goes through it. The lyrical protagonist, though physically healthy and seemingly calm, has an inexplicable pain in his heart, an insurrection in his heart, an appetite for disease, and:

To the heart of the ulru usrukka giriftor,

Sogmen vale in the eye of the hand is self-sick (157), -

analyzes his condition. The lyrical protagonist the seeker becomes involuntary in demand. There is a growing demand for desperation in the heart. The mind, more than the instruction of the mind, listens to the will and considers it to be a complete destiny:

Although you don't want to decide,
manga,

It is the work of the will, not the will of the manga (54).

The Taliban need the guidance of a spiritual leader so that he does not get lost at the beginning of the path. Talib surrenders his will to the pir and, with the help and support of his teacher, becomes aware of Jordan. In this regard, there are a number of images in the gazelles. In them, the narrator, the messenger, the artist, the supportive guide to the Taliban are embodied as human beings. Through them, Talib receives the message of Yor:

If a narrator narrates a word,

I'd like a story about a squirrel.

I'm crazy, I'm on my own, I'm not,

If anyone narrates a word from that paridin (67)

In such poems, the lyrical protagonist strives for Yorga in a daze, wandering, astonished, confused, and considers it a blessing that Yor is blessed with a look, a frown, a frown, and a kiss. Talib's passion, Yorga's captivity, gradually affects his image as well as his biography, and the heart reveals its other qualities. These qualities prove that the Taliban has fallen in love. In contrast to the gazelles in the status of demand, the gazelles in the status of love describe the sufferings of separation, images of migration, destruction, and brokenness. "Yor's indifference, ignorance of the lover's condition, his ruthlessness, the lover's weakness, suffering are absorbed into the essence of such poems." In romantic poems, Yor's rejection of love as a science of cruelty is a grace. Because this action of Yor teaches the lyrical protagonist to endure all the hardships in order to observe his condition and achieve his guardianship. The flame of love, on the other hand, is the suspicion in the heart - it burns all vices to ashes. A true lover will not take anyone's pandu advice. Although she is forced to give up her love for Crazy Example Layla, otherwise she becomes more attached to this love. Love poems often describe the lyrical protagonist living in the desert, interacting with animals rather than people, people laughing at him and children mocking him. described in a special plan:

Seventy faces of grief appeared on my face,

Borgali eldek spring nozparvardim mine.

I always talk to myself like crazy,

Chun is my sympathy in a world other than myself (294). 
In romantic poems, the lover is guided by a doctor, a judge, a friend, a guide, and another character, a rival. It has been pointed out above that the inner world of the Taliban is not reflected in appearance, but the state of the lover is equally manifested in the heart and soul, and the lover is characterized by the qualities of sorrow, poverty, gloom, mourning, hardship, weakness, trauma, affliction, poverty, sickness. The heart, tormented and wounded by love, feels the need for loving love and protection. It is a state that is clearly manifested in the lover's appearance and heart. The poet describes this situation as follows: Orzuyi vaslidin ranjur erur munglug ko'ngul, Gado as a patient with tazvir for kut (64).

This state of mind is changed by the courtesy of Yor. If a lover is blessed with the grace of God, he will forget his illness and weakness. Even every word about Yorga can change your mood. The great poet writes about this:

A hundred jilvas to your stature at all times, $\mathrm{O}$ beautiful sapling, In my ignorant heart every jilvas is different (347).

The state of the lover's shock, aphthous, ruin, ruin, fracture, trauma represents a state of rejection, but not renunciation of love. The mind in this state radiates from the light of contemplation, is given to the observation of the environment, and is quick and quick on the path of self-realization:

My wicked soul is surrounded by blood, Erur vayronaekim, tulips butgay bahor andin (440).

Or:

I have little grief in my heart,

The broken wing looks like a stone to a broken bird's eye (167).

Yor's traditional suffering and disregard for his lover has a strong effect on the lyrical protagonist's emotional, mental, and physical state. In this case, the lover will be rich and strong from the inside, even if he looks aphthae, ruined, broken. For in this state the flame of love enlightens the senses, and the dust in the heart is cleansed by tears. In this case, his words are noteworthy:
Sinsa read in my heart, rubbing hot blood on it,

Pay masalik chirmagaymen rishtayi jondin anga (48).

The foundation of the heart is strong with love. When a partner refuses love, it really hurts the lover's heart. Then the mind will observe its state and reality more deeply, will be alert to everything. From this vigilance he turns on the light of enlightenment and turns from a lyrical hero - a lover to a sage.

Alisher Navoi's poetry is enlightening poetry. The determining factor of the poet's poetry is his enlightenment. It can be said that enlightenment is the essence of the great poet's poetry. The essence of this ore is conveyed to the reader through the observations of the lyrical hero - Arif. After all, arif is an Arabic word that means the possessor of gnosis. According to mystical dictionaries, "Arif is the knower, the knower, the acquaintance, the knower, the understandinger, the possessor of perfect knowledge. The one who observes Allah, His attributes and names is Arif. Although it comes in a cognitive sense like a scientist, it is different from a wise scientist. When a scientist achieves a goal with scientific knowledge and aspiration, the enlightened person attains enlightenment through inspiration and state. It is a characteristic of the Arif to know Allah through the situation and observation. The lyrical protagonist of Alisher Navoi's ghazals is Arif, who is a perfect person who teaches the power of love, submission of the heart, sincerity of spirit, silence of mystery, observation of himself and his identity.

In general, the lyrical hero in the poems of Alisher Navoi literally expresses the poet himself. There is no doubt that the Taliban's aspirations on the path of demand and the sufferings, passions and excitements of the lover in the valley of love, or the observations of the sage described in the ghazals, are a reflection of the great poet's own experiences and circumstances. Therefore, a comprehensive and comprehensive study of the issue of the lyrical hero in the poetry of the thinker-poet can be considered as one of the most important works in the understanding of Navoi. 


\section{REFERENCE}

[1] Literary encyclopedic dictionary. - M: S E, 1987. p. 185

[2] Hotamov N., Sarimsoqov B. Dictionary of Literary Terms. -p. 165.

[3] Mamajonov S. The issue of lyrical hero in poetry // Sharq yulduzi. -Tashkent: 1961, №9. - p. 9 .

[4] Norboev B. Talent, faith, time. - Tashkent: Literature and art, 1981. -p. 216.

[5] Hayitmetov A. Navoi lyrics. -Tashkent: Uzbekistan, 2015. p.170.

[6] Hayitmetov A. Navoi lyrics. Page 171

[7] Shayxzoda M. The lyrical hero of Navoi / The great Uzbek poet. -Tashkent: Fan, 1948. Pages 131-158. Hayitmetov A. Navoi lyrics. -Tashkent: Fan, 1961.

[8] Pulotjonovna N. B. Latest Studies of Latoif in Stories // International Journal of Progressive Sciences and Technologies. 2020. - T. 19. - №. 1. - p. 158-161.

[9] Bozorova N. P. sposob izucheniya predmeta Officenyx dokumentov vo vremya pandemii // review of law sciences. - 2020. - №. 2.

[10] Ramazonov N. et al. interpretation and artistic function of the concept of faqr in alisher navoi's lyrics // interpretation. 2020. - t. 29. - №. 5. - p. 1633-1641.

[11] Ramazanov n. poetic interpretation of the concept of fakir in the lyrics of alishera navoi // Theoretical \& Applied Science. 2019. - №. 7. - p. 344-347.

[12] RAMAZONOV N. Editing the edition in Alisher Navoi // Editing the Editing in 'Alī Shīr Nawā's Poetry], Uzbek language and literature. - 2006. - №. 1. - p. 17-23. 